\title{
Gaming and Museum
}

\author{
Filomena Izzo \\ University of Campania “Luigi Vanvitelli”, Capua, Italy
}

\begin{abstract}
The purpose of this research paper is to investigate the state of the art of gaming applications in museums in order to reach audience development and community engagement. After analysing the main challenges concerning the innovation of the museum sector, this review tries to build a theoretical framework linking changes in audiences, museum role, and strategies for visitor involvement to support cultural institutions in achieving their mission and maximizing value creation. The research methodology employs a qualitative exploratory multi-case study. The key concept that emerges from the study, is that the museum is comparing with a variety of audiences in constant evolution, with respect to which is necessary to identify correct and appropriate arrangements for dialogue, declining languages, and tools of mediation in keeping with museum dissemination objectives. Moreover, a museum, to be able to communicate in an appropriate way, must first know how to listen to all its visitors, even (or especially) those of a younger age, often not attracted by history and art but generally gamers who, if appropriately involved, could ultimately represent its visitors of the future. The study aims to be a tool for reflection for cultural institutions which want to revitalize their offering system.
\end{abstract}

Keywords: gaming, museum, audience engagement, audience development, cultural heritage

Just 40 years after their birth, video games have become one of the main creative and entertainment industries in the world. No wonder a projected turnover of more than $\$ 100$ billion in 2017 (Report Newzoo), for years now has passed cinema, music, and books for business volumes. A recent report on cultural and creative industries in England shows how the sector "IT, software and games" in 2014 has generated indirect economic value than "movie, television, music, publishing, design, fashion, and architecture" put together.

We are talking, therefore, of a sector of huge importance worldwide, which is able to produce wealth and generate high economic value. It is not, therefore, something confined to a marginal and minority audience (teenagers), as a superficial approach might suggest, but rather of a growing business, which has moreover gradually expanded its range of users, also in unpredictable directions.

Now, it makes this necessary initial clarification, and it seems appropriate to ask about what is, or could be, the link between the world of video games and that of museums. In the first instance, it should be noted that not only there are many museums whose collections are composed essentially of video games but also some museums, caliber (for example) of the MOMA (The Museum of Modern Art), have interpreted these productions as a true artistic expression, to the point of them become an integral part of its permanent collections. In other cases, video games have been the subject of temporary exhibitions, such as one called "The Art of Video Game", created in 2012 by the SAAM, the Smithsonian American Art Museum in Washington.

Corresponding author: Filomena Izzo, researcher, assistant professor in management at Economics Department of University of Campania "Luigi Vanvitelli", Capua, Italy; research fields: museum management, cultural heritage management, tourism destination management. 
The game could be an informal learning context, to catch the interest, in the first instance of the youngest and induce them to create a new or a different relationship with the world of museums. In fact, the aim of the video game has been identified in accompanying the (young) visitors on an exploration of non-conventional museum spaces, thus maximizing their impact in terms of involvement and active participation. Aspects, as is known, are essential for improving the effectiveness of cognitive processes in an "edutainment" perspective.

Related to this, there is the "accessibility" issue, because it concerns the life of the museum and, in particular, its ability to reduce the barriers that may hinder its multiple relationships with its various audiences, undermining the foundations of its very existence.

About digital accessibility, the new communication technologies are acquiring an increasingly important role, not only in museums but also in the lives of each of us: The unstoppable spread of smartphones and tablets - which, soon, will be added with the new "wearable" devices, that is wearable, such as smart watch and smart glass - must be considered by the museum in the selection of communication tools that can be taken, with its "real" (visitors) and "digital" users; digital users are those who come into contact and establish a relationship with the museum through the Internet. In the next sections, after showing scientific debate on "museum audience approach" and the changing role of museums in our society, methodology and results are discussed.

\section{Theoretical Background}

Analysing strategies for visitor involvement, participation should not only be connected to the option of museum as a social practice, involving social interaction with other visitors and dialogue with exhibitions (Coffee, 2007), but also be considered a dimension of accessibility, firmly linked to the use of the museum as a public space (Hautio, 2011). To become relevant organisations, it is essential that museums adopt new participatory practices (Nielsen, 2015): Engagement means new presentation and reading techniques through videos and audios, interactive panels, guided tours, and interactive exhibitions (Taheri, Jafari, \& O'Gorman, 2014).

As a consequence, the approach based on one-way mass communication is considered bygone and even the concept of different clusters of users based on socio-demographic categories is facing a crisis in favour of a new paradigm based on the concept of "identity formation in everyday life", where visitors are simultaneously "members of an audience (cultural consumers) and performers (cultural producers)" (Stylianou-Lambert, 2010, p. 135).

Moving from this new approach, visitor studies have emphasized the need to encourage the participation of museum users in different forms (Simon, 2010), even through co-production (Davies, 2010). According to a constructivist approach, "museum exhibitions have to be designed and set up as an open work, providing different perspectives and viewpoints, to facilitate open-ended learning outcomes" (Sandell, 2007, p. 78).

In particular, the role of new technologies and the digital empowerment of museums have been considered crucial in attracting young generations and new audiences (Parry, 2007; Marty \& Burton-Jones, 2008; Tallon \& Walker, 2008; Carrozzino \& Bergamasco, 2010; Bakhshi \& Throsby, 2012; Jarrier \& Bourgeon-Renault, 2012; Howell \& Chilcott, 2013; Alexandri \& Tzanavara, 2014; Enhuber, 2015). Both academics and practitioners highlight this idea: Thanks to edutainment, interactivity, and immersive experiences (Mencarelli, Marteaux \& Pulh, 2010; Brady, 2011; Ntalla, 2013), ICTs (Information and Communication Technologies) could stimulate people's commitment, understanding, and creative engagement (Dindler, 2014), also becoming an activating factor in lack of motivation and context (Baradaran-Rahimi, 2014). Even though there is a risk of dramatization, trivialization, and Disneyfication resulting from technologies (Balloffet, Courvoisier, \& Lagier, 2014), ICTs can 
create effective narrative environments (Macleod, Hanks \& Hale, 2012), facilitating the communication of the historical value of the exhibits through storytelling, thematization, spatialization, and scenarization (Mencarelli et al., 2010). At last, in Internet era, more attention has been paid to the role of social media and their application in the museum sector from one-way to multi-way communication strategies (Srinivasan, Boast, Furner, \& Becvar, 2009; Chae \& Kim, 2010; López, Margapoti, Maragliano, \& Bove, 2010; Fletcher \& Lee, 2012; Marakos, 2014; Gronemann, Kristiansen, \& Drotner, 2015; Pulh \& Mencarelli, 2015).

As an outcome, visitor involvement has gained a central role: Audience participation and engagement have been implemented through ICTs, promoting edutainment, interactivity, immersive experiences, and narrative environments (Izzo, Mustilli, \& Guida, 2015; Izzo, Mustilli, Sasso, \& Solima, 2016a; 2016b; Cerquetti, 2016). Given the above analysis, the study advances the following propositions:

P.1. Museum new audience: digital natives;

P.2. New role of museums: from being about something to being for somebody; from exclusive to inclusive spaces; from places of education to places of learning;

P.3. New strategies for visitor involvement: new technology and museum digital empowerment; edutainment, interactivity, immersive experiences, and narrative environments.

\section{Methodology}

The paper reports an exploratory multiple case study in order to better understand about these issues (Eisenhardt \& Graebner, 2007). In general, the case study research method is suitable when the form of the research question is "how", there is no need of control on events, and the analysis is on contemporary events (Yin, 2009). In particular, the method of exploratory case study is useful when preliminary propositions and hypotheses are absent (Mills, Durepos, \& Wiebe, 2010).

The sample was composed specifically of museums that use technology extensively, in particular use game app to improve visiting experience. The study analysed following museums: American Museum of Natural History (USA), Tate Museum (UK), Smithsonian American Art Museum (USA), British Museum (UK), Réunion des Musées Nationaux (France), Walter Art Museum in Baltimore (USA), and Science Museum in London (UK).

Data collection consisted of information from: museum websites and web pages; interviews with museum experts and institutional partners; and communication reports and guidelines.

\section{Results}

The case studies show that museums are reversing their perspective, abandoning the self-reflective approach, in order to be really accessible, and they have realized that it is necessary "to listen", avoiding standardized solution based on an overly simplified view of reality. Because the reality with which musem is confronted, every day, is diverse and multifaceted. So, the people with the museum establish a relationship, whether it goes on time to visit, whether it extends over a period, also thanks to the Internet and the new digital media.

Museums are looking at video games as both an art form and a way to reach a wider audience. The games have shown the positive impacts in terms of the audience development, audience engagement, and all over the user's path: pre-during-post experience.

The museums examined use game-like mechanics to didactic exercises in delivering information. Barry Joseph, associate director of digital learning at the American Museum of Natural History affirmed: 
We want to offer something to people that makes them want to leave their home, come to the museum, and experience something and it also gives them an opportunity to not only appreciate, but actually connect with the objects themselves.

An evolution varies fast, then, involves technology expression and audience participation, pushing each institution not only to a constant adaptation, but also to the development of new strategies designed and programmed for a growing increase in the quality of the treatment of its public involvement, anticipating changes, trends, and needs of their audiences to develop interconnections, multi-disciplinary and new narrative paths: The culture becomes more and more communicative, formative, active, creative, and multidisciplinary, in a strategic process in order to develop its resources.

A culture that advances in terms of research, experimentation, and sharing to co-design, co-produce, and co-create new logic, formulas, and enhancement methodologies; that looks so effective to the development of a good engagement, how to properly promote their "cultural value added", element that even in the recent past was considered "collateral", and that today, however, thanks to its connective digital effect, is increasingly foundational element of social architecture that wants to be truly integrated and concrete.

\section{Conclusions}

Finally, the key concept that emerges from the study, is that the museum is confronted with a variety of audiences in constant evolution, with respect to which is necessary to identify correct and appropriate arrangements for dialogue, declining languages, and tools of mediation in keeping with museum dissemination objectives.

More, a museum, to be able to communicate in an appropriate way, must first know how to listen to all its visitors, even (or especially) those of a younger age, often not attracted by history and art but generally gamers who - if appropriately involved — could ultimately represent its visitors of the future.

In this sense, the European Commission itself identifies in cultural digital access one of the major strategic issues of the next development (including economic) of the entire EU. This is demonstrated by the many open calls for funding already at the beginning 2017, both within a Horizon 2020 (participatory approaches and social innovation in cultures) and in the cultural sector of Creative Europe (call for platforms active in the cultural and creative sectors) or even with Europeana and Pluggy project, the latter is a new virtual community platform, based on crowdsourcing content and responding to the needs of European society to be actively involved in activities related to their own cultural heritage.

Video games themselves are one of the most fresh and lively, artistic and cultural expressions of our time beyond the idea of a purely creative product and entertainment. The video games, and in general the logic of gamification, allow museum to bring "out of the museum" to reach new audiences in ways and languages known by these new visitors. Also video games allow a new type of narrative and immersion experience, called "storydoing", the player becomes active protagonist of the story in which he constantly makes decisions and it even alters the final. Finally, the video game is one of the tools that enables cultural institution in keeping the contacts and involvement even after direct experience. The study aims to be a tool for reflection for cultural institutions that want to revitalize their offer, supporting cultural institutions in achieving their mission and maximizing value creation.

\section{References}

Alexandri, E., \& Tzanavara, A. (2014). New technologies in the service of museum education. World Transactions on Engineering and Technology Education, 12(2), 317-320. 
Bakhshi, H., \& Throsby, D. (2012). New technologies in cultural institutions: Theory, evidence and policy implications. International Journal of Cultural Policy, 18(2), 205-222.

Balloffet, P., Courvoisier, F. H., \& Lagier, J. (2014). From museum to amusement park: The opportunities and risks of edutainment. International Journal of Arts Management, 16(2), 4-18.

Baradaran-Rahimi, F. (2014). A model for sociocultural interactions in museums. Museum Management and Curatorship, 29(2), 174-187.

Brady, M. J. (2011). Subjectivity through self-education: Media and the multicultural citizen at the national museum of the American Indian. Television \& New Media, 12(5), 441-459.

Carrozzino, M., \& Bergamasco, M. (2010). Beyond virtual museums: Experiencing immersive virtual reality in real museums. Journal of Cultural Heritage, 11(4), 452-458.

Cerquetti, M. (2016). More is better! Current issues and challenges for museum audience development: A literature review. ENCATC Journal of Cultural Management and Policy, 6(1), 30-43.

Chae, G., \& Kim, J. (2010). Rethinking museum management by exploring the potential of social tagging systems in online art museums. International Journal of the Inclusive Museum, 3(3), 131-140.

Coffee, K. (2007). Audience research and the museum experience as social practice. Museum Management and Curatorship, 22(4), 377-389.

Davies, S. M. (2010). The co-production of temporary museum exhibitions. Museum Management and Curatorship, 25(3), 305-321.

Dindler, C. (2014). Designing infrastructures for creative engagement. Digital Creativity, 25(3), 212-223.

Eisenhardt, K. M., \& Graebner, M. E. (2007). Theory building from cases: Opportunities and challenges. Academy of Management Journal, 50(1), 25-32.

Enhuber, M. (2015). Art, space and technology: How the digitisation and digitalisation of art space affect the consumption of art-A critical approach. Digital Creativity, 26(2), 121-137.

Fletcher, A., \& Lee, M. J. (2012). Current social media uses and evaluations in American museums. Museum Management and Curatorship, 27(5), 505-521.

Gronemann, S. T., Kristiansen, E., \& Drotner, K. (2015). Mediated co-construction of museums and audiences on Facebook. Museum Management and Curatorship, 30(3), 174-190.

Hautio, M. (2011). '[...] But it's not like I know anything about them!': Immigrants in the museum in Finland. Public Archaeology, 10(2), 68-95.

Howell, R., \& Chilcott, M. A. (2013). Sense of place: Repurposing and impacting historical research evidence through digital heritage and interpretation practice. International Journal of Intangible Heritage, 8, 165-177.

Izzo, F., Mustilli, M., \& Guida, M. (2015). Realtà aumentata e valorizzazione dei beni culturali. Riflessioni sull'offerta culturale casertana (Augmented reality and cultural heritage promotion. Reflections on Caserta cultural offering). Proceedings from the Sinergie Annual Conference, July, Termoli, Italy.

Izzo, F., Mustilli, M., Sasso, P., \& Solima, L. (2016a). Service orientation and technology innovation in museum: Museo Archeologico Nazionale of Naples case study. Proceedings from 26th Annual RESER Conference, September, Naples, Italy.

Izzo, F., Mustilli, M., Sasso, P., \& Solima, L. (2016b). Smart tourism destination from IOT perspective: Adaptive orientation system. Proceedings from 6th International Conference on Tourism (ICOT), September, Naples, Italy.

Jarrier, E., \& Bourgeon-Renault, D. (2012). Impact of mediation devices on the museum visit experience and on visitors' behavioural intentions. International Journal of Arts Management, 15(1), 18-29.

López, X., Margapoti, I., Maragliano, R., \& Bove, G. (2010). The presence of Web 2.0 tools on museum websites: A comparative study between England, France, Spain, Italy, and the USA. Museum Management and Curatorship, 25(2), 235-249.

Macleod, S., Hanks, L. H., \& Hale, J. (2012). Museum making. Narratives, architectures, exhibitions. Oxon: Routledge.

Marakos, P. (2014). Museums and social media: Modern methods of reaching a wider audience. Mediterranean Archaeology \& Archaeometry, 14(4), 75-81.

Marty, P. F., \& Burton-Jones, K. (2008). Museum informatics: People, information, and technology in museums. London-New York: Routledge.

Mencarelli, R., Marteaux, S., \& Pulh, M. (2010). Museums, consumers, and on-site experiences. Marketing Intelligence \& Planning, 28(3), 330-348.

Mills, A. J., Durepos, G., \& Wiebe, E. (2010). Encyclopedia of case study research (Vols. I/II). Thousand Oaks, CA: Sage. 
Nielsen, J. K. (2015). The relevant museum: Defining relevance in museological practices. Museum Management and Curatorship, 30(5), 364-378.

Ntalla, I. (2013). Engaging audiences on ongoing social debates through interactive and immersive exhibits. International Journal of the Inclusive Museum, 6(2), 105-116.

Parry, R. (2007). Recoding the museum. Digital heritage and the technologies of change. London-New York: Routledge.

Pulh, M., \& Mencarelli, R. (2015). Web 2.0: Is the museum visitor relationship being redefined? International Journal of Arts Management, 18(1), 43-51.

Sandell, R. (2007). Museums, prejudice and the reframing of difference. London: Routledge.

Simon, N. (2010). The participatory museum. Santa Cruz, CA: Yaylor \& Francis.

Srinivasan, R., Boast, R., Furner, J., \& Becvar, K. M. (2009). Digital museums and diverse cultural knowledges: Moving past the traditional catalog. Information Society, 25(4), 265-278.

Stylianou-Lambert, T. (2010). Re-conceptualizing museum audiences: Power, activity, responsibility. Visitor Studies, 13(2), 130-144.

Taheri, B., Jafari, A., \& O'Gorman, K. (2014). Keeping your audience: Presenting a visitor engagement scale. Tourism Management, 42, 321-329.

Tallon, L., \& Walker, K. (2008). Digital technologies and the museum experience: Handheld guides and other media. Lanham, MD: Altamira Press.

Yin, R. K. (2009). Doing case study research (4th ed.). Thousand Oaks, CA: Sage. 